OPEN ACCESS

Edited by:

James K. H. Tsoi,

The University of Hong Kong,

Hong Kong, SAR China

Reviewed by:

Hao Yu,

Fujian Medical University, China

Akikazu Shinya,

Nippon Dental University, Japan

Jie Lin,

Fujian Medical University, China

*Correspondence:

Anchun Mo

moanchun@163.com

Specialty section:

This article was submitted to

Dental Materials,

a section of the journal

Frontiers in Dental Medicine

Received: 31 March 2021

Accepted: 07 June 2021

Published: 03 August 2021

Citation:

Lin H, Yin C and Mo A (2021) Zirconia Based Dental Biomaterials: Structure,

Mechanical Properties,

Biocompatibility, Surface Modification, and Applications as Implant.

Front. Dent. Med. 2:689198.

doi: 10.3389/fdmed.2021.689198

\section{Zirconia Based Dental Biomaterials: Structure, Mechanical Properties, Biocompatibility, Surface Modification, and Applications as Implant}

\author{
Hua Lin ${ }^{1,2}$, Cuilan Yin ${ }^{1}$ and Anchun Mo ${ }^{\text {* }}$ \\ ${ }^{1}$ State Key Laboratory of Oral Diseases, National Clinical Research Center for Oral Diseases, West China Hospital of \\ Stomatology, Sichuan University, Chengdu, China, ${ }^{2}$ Division of Advanced Prosthetic Dentistry, Graduate School of Dentistry, \\ Tohoku University, Sendai, Japan
}

Zirconia, with its excellent mechanical properties, chemical stability, biocompatibility, and negligible thermal conductivity, is ideal for dental and orthopedic applications. In addition, the biocompatibility of zirconia has been studied in vivo, and no adverse reactions were observed when zirconia samples were inserted into bone. However, their use is controversial among dentists and researchers, especially when compared with mature implants made of titanium alloy. The advantages and limitations of zirconia as biomaterials, such as implant materials, need to be carefully studied, and the design, manufacture, and clinical operation guidelines are urgently required. In this review, the special components, microstructure, mechanical strength, biocompatibility, and the application of zirconia ceramics in biomaterials are detailly introduced. The review highlights discussions on how to implement innovative strategies to design the physical and chemical properties of zirconia so that the treated zirconia can provide better osteointegration after implantation.

Keywords: zirconia, dentistry, biocompatibility, mechanical properties, surface modification, osteointegration, implant

\section{INTRODUCTION}

The word "pottery" comes from the Greek word "keramos" (1), which means pottery or burned objects. Ceramics are usually inorganic, non-metallic, and are cooled by proper heat treatment, and are subjected to subsequent treatment to synthesize solids. Zirconium dioxide $\left(\mathrm{ZrO}_{2}\right)$ nanoparticles are one of the nanomaterials mainly used in the synthesis of refractories, foundry sand, and ceramics (2-4).

Zirconium dioxide, a bioceramic, was first proposed in 1789 by German chemist Martin Heinrich Klapropse (5). $\mathrm{ZrO}_{2}$ began to play a role as a biomaterial in 1969 when researchers described its use in biomedical sciences. The application of $\mathrm{ZrO}_{2}$ in dental prostheses has been underway since 1995 (6). The strongest dental ceramics on the market are $3 \mathrm{~mol} \%$ yttria-stabilized quadrilateral zirconia polycrystals (3Y-TZPs), known simply as $\mathrm{ZrO}_{2}$. Because $\mathrm{ZrO}_{2}$ has high strength, hardness, wear resistance, corrosion resistance, similar to the elastic modulus of steel and iron, similar thermal expansion coefficient, and high fracture toughness and chemical properties, 
$\mathrm{ZrO}_{2}$ has been widely used in biomedical fields, such as used in biosensors, cancer treatment, and hip replacement. $\mathrm{ZrO}_{2}$ can also be used for dental crowns, post and implant $(7,8)$. The biocompatibility of $\mathrm{ZrO}_{2}$ has been widely evaluated, and there has been a significant increase in the number of $\mathrm{ZrO}_{2}$ based ceramics used as biomaterials in dentistry, which has been confirmed in both in vivo and in vitro studies (9).

At present, $\mathrm{ZrO}_{2}$ is widely used in dentistry. $\mathrm{ZrO}_{2}$ is used in dental implants, abutments, crown prostheses, and post $(10,11)$. One of the trends in dental implants is the development of new ceramic-based implants to enhance the ability of periodontal integration and long-term firm adhesion with the surrounding tissues, such as osseointegration (1214). $\mathrm{ZrO}_{2}$ surface characteristics determine implant success and survival after implantation. These characteristics include implant microstructure, surface composition and properties, and design factors (15). The antimicrobial ability of $\mathrm{ZrO}_{2}$, or the ability of its surface to reduce plaque accumulation, is an important property to improve the quality and volume of soft tissues and is considered as an alternative to titanium implants. Compared with other types of ceramic materials, yttrium stabilized tetragonal zirconia (YTZ) has better fracture toughness and bending strength, as well as excellent wear resistance, corrosion resistance, high-temperature resistance, oxidation resistance, and hydrophilic properties (16-20). These properties can solve the problems of strength and toughness deficiency of traditional ceramic materials. The seven aspects of introducing the application of zirconia as implants: (1) the zirconium oxide as the biological safety of the implants, (2) improve the osteogenesis effect after zirconium oxide within the bone graft, (3) improve the zirconia affinity with the surrounding soft tissues, (4) a new type of molding technology of zirconium oxide, (5) the methods of surface modification of zirconium oxide to improve biological safety, (6) zirconium oxide application prospect as an implant, and (7) the disadvantages of the application of $\mathrm{ZrO}_{2}$ in the dental field.

\section{BIOSAFETY OF $\mathrm{ZrO}_{2}$}

The surface morphology of biomaterials plays an important role in determining cellular response. Different surface treatment methods are used (21).

The surface morphology and chemical composition of $\mathrm{ZrO}_{2}$ can be improved to enhance osseointegration (22-24). $\mathrm{ZrO}_{2}$ toughened alumina (ZTA) is a kind of material combining the unique characteristics of $\mathrm{ZrO}_{2}$ and alumina $\left(\mathrm{Al}_{2} \mathrm{O}_{3}\right)$, which has been widely used. The advantage of ZTA is that it eliminates the individual limitation of $\mathrm{ZrO}_{2}$ and $\mathrm{Al}_{2} \mathrm{O}_{3}$, and has rich biocompatibility and aging resistance. In addition, the results of in vitro cytotoxicity test proved that the $\mathrm{Tb}^{3+}$ doped ZTA composites had better biocompatibility. Some studies have shown that the quality and quantity of plaque adhesion to the surface of $\mathrm{ZrO}_{2}$ is a key factor in maintaining the health of the surrounding tissues and determining the success of $\mathrm{ZrO}_{2}$ cultivation (25-28). The presence of a micro space between the implant fixation and the abutment has been considered as a possible etiology. According to in vitro and in vivo models, this microleakage may play a role in bacterial growth and pathogenesis around zirconia. Recent studies have shown that fewer bacteria accumulate around yttrium zirconium ceramics (Y-TZP), reducing the incidence of peri-implantitis and increasing the long-term outcome of implants $(25,29)$.

Some scholars have measured the steady wear rate of several ceramics in the abrasive slurry test (30-33). The wear rate of the test cylinder was measured by turning it over in a variety of water-borne abrasive slurries. Mg-PSZ is the most wearresistant material tested, only $0.05-0.2$ of the wear rate of alumina. The impressive wear resistance of PSZ discussed above is the result of the surface strengthening phenomenon in which the tetragonal $\mathrm{ZrO}_{2}$ precipitates are converted to a monoclinic structure through a specific wear process (34-37). The area of wear is, therefore, in a state of compression, and this compression tends to inhibit further removal of the material. The study aims to report the biocompatibility of PSZ based on preliminary results from in vitro and in vivo trials (38).

\section{EXPLORATION OF ENHANCING THE OSTEOGENIC ABILITY OF $\mathrm{ZrO}_{2}$}

In dentistry, there are several types of bone graft materials that can be used directly for bone grafting $(39,40)$. An ideal feature of bone scaffolds is their ability to resist the functional load. Allergic reactions caused by some metal alloys are a disadvantage of metal prostheses, which have prompted the research and application of more biocompatible ceramic prostheses (41). $\mathrm{ZrO}_{2}$ has high bending strength (900-1,200 MPa), excellent hardness (1,200 Vickers), low thermal conductivity, strong corrosionresistance and biocompatibility, reducing platelet aggregation, surface wettability, surface energy, and surface morphology (42). In general, $\mathrm{ZrO}_{2}$ based ceramics are chemically inert and have no adverse reactions to general tissues, and have been designed for clinical use in recent years. Partially stable $\mathrm{ZrO}_{2}$ is used in dental implants for its osseointegration, good biocompatibility, high strength, compressive resistance, and crack growth resistance. The biosafety and biocompatibility of $\mathrm{ZrO}_{2}$ and the interaction of bone/zirconia have been studied. The long-term success of the implant is largely dependent on the ability of the material to blend with its surroundings. $\mathrm{ZrO}_{2}$ dental implants are a better alternative to conventional immediate implants because they can use CAD/CAM technology into the shape of the root. In hard tissue engineering, calcium phosphate (CAP) ceramics, such as hydroxyapatite and tricalcium phosphate, have attracted wide attention due to their excellent biocompatibility and bone conductivity (43). Most clinical reports indicate that their poor mechanical properties, such as low strength and fracture toughness, limit their widespread use in hard tissue implants. Among all kinds of zirconia, Y-TZP is the main component of $\mathrm{ZrO}_{2}$ implants and is considered as an orthopedic biomaterial. Studies from cell cultures to full-scale animal models have shown that the osseointegration observed on the optimized $\mathrm{ZrO}_{2}$ surface is as good as, or better than, different materials (i.e., titanium alloys). Porous zirconia scaffolds can also be used as drug delivery 
carriers to enhance bone response. Biological responses to dental implants are determined by several physical and chemical characteristics of the implant surface, including mechanical and physicochemical properties (44). $\mathrm{ZrO}_{2}$ coating can induce the accumulation of apatite in the simulated body fluids, which can promote the adhesion and proliferation of osteoblasts. $\mathrm{ZrO}_{2}$ as hydroxyapatite (HAP) $/ \mathrm{ZrO}_{2}$ composite material can improve the low bond strength caused by the mismatch of thermal expansion coefficient between porous HAP and main alloy components, thus promoting bone regeneration. Several studies have evaluated the reaction of bone with optimized zirconia scaffold surfaces. A recent study attributed the increase in cell survival to the internal structure of the scaffold, rather than the types of coating material used (45).

Some scholars prepared nHA/PA66/YTZ bone screws, implanted them into the joints of rabbits, and studied their biocompatibility and bioactivity in vivo. For aesthetic reasons, zirconia has been used as implant material in clinics. The high elastic and thermal modulus, low plaque affinity, and high biocompatibility of $\mathrm{ZrO}_{2}$ ceramics may make them an alternative to titanium in implant dentistry. In addition, $\mathrm{ZrO}_{2}$ had an inhibitory effect on bacterial colonization.

\section{EFFECTS OF $\mathrm{ZrO}_{2}$ ON SOFT TISSUE}

Because ceramic implants are made with a polished surface at a very high temperature, they can reach the gingival tissue and help with the maintenance of gingival structures (46). Several studies in various animals have reported zirconium peroxide as a ceramic material for soft tissue implantation, followed by the analysis of systemic toxicity and adverse reactions in soft tissues $(47,48)$. After implantation, the zirconia material was wrapped in a thin layer of fibrous tissue for 12 weeks, regardless of the time of implantation. In all cases, $\mathrm{ZrO}_{2}$ did not produce any form of adverse tissue reactions, indicating that $\mathrm{ZrO}_{2}$ is a biocompatible ceramic material. In conclusion, zirconia do not cause cytotoxicity in soft tissues, even if it is intraperitoneally injected and fibers are found in the lymph nodes. $\mathrm{ZrO}_{2}$ and titanium were used as soft tissue implants. Compared with $\mathrm{ZrO}_{2}$, the inflammatory infiltration, microvessel density, and vascular endothelial growth factor expression around titanium implants were higher. In addition, cell proliferation on the surface of $\mathrm{ZrO}_{2}$ was also higher than that on the surface of titanium (39).

$\mathrm{ZrO}_{2}$ powders of 87 kinds were tested with different cell lines and extracts were extracted by different methods (cell viability and MTT analysis) (49). When the fibrous cells were co-cultured with $\mathrm{ZrO}_{2}, \mathrm{ZrO}_{2}$ had no cytotoxic effect. The $3 \mathrm{~T} 3$ fibroblasts were more adhesive and diffusive on the $\mathrm{ZrO}_{2}$ material observed by using scanning electron microscopy. The cytotoxic effects of $\mathrm{ZrO}_{2}$ - Yttrium oxide $\left(\mathrm{Y}_{2} \mathrm{O}_{3}\right)$ on human lymphocyte mitogen were compared with those observed in the culture (50). It was confirmed that the cytotoxic effects of alumina and $\mathrm{ZrO}_{2}$ were similar and lower than those of $\mathrm{TiO}_{2}$. In the study on the colonization of bacteria in $\mathrm{ZrO}_{2}$, some scholars have observed many ectopic epithelial cells on the surface of $\mathrm{ZrO}_{2}$, suggesting that $\mathrm{ZrO}_{2}$ may be a promising material that can enhance the adhesion of epithelial cells (51-53).

\section{ZIRCONIUM DIOXIDE FORMING TECHNOLOGY TO IMPROVE BIOCOMPATIBILITY}

Traditional ceramic molding methods, such as dry pressing, isostatic pressing, sliding casting, strip casting, and injection molding, have been used to prepare ceramics (54-56). However, these traditional ceramic forming techniques have some limitations, such as they cannot be used for parts with complex shapes (with inner holes, sharp corners, etc.) and parts requiring high precision. The traditional ceramic molding process needs mold manufacturing and post-treatment, and it is time-consuming and expensive $(57,58)$. The last decade has also witnessed the development of new processing technologies for producing zirconia, such as CAD, CAM, and rapid prototyping. In addition, some researchers have used the water system of solgel, powder pulp, and bionic solution to form the uniform coating on the surface of zirconia through the complex shape of implants and porous bone scaffolds.

Some scholars have prepared the cap ceramic and glass composite coatings on $\mathrm{ZrO}_{2}$ substrate. $\mathrm{ZrO}_{2}$ ceramics are widely used as substrates in hard structures due to their excellent strength and fracture toughness. Cap- $\mathrm{ZrO}_{2}$ composite materials and Cap-coated porous $\mathrm{ZrO}_{2}$ scaffolds have proved their excellent mechanical properties and cellular responses (59).

Due to its rapid prototyping technology, stereolithographic 3D (SLA-3D) printing technology has been widely used in the preparation of complex $\mathrm{Al}_{2} \mathrm{O}_{3}, \mathrm{ZrO}_{2}$, and $\mathrm{HAP}$ ceramic parts (60).

Zirconia toughened alumina ceramics (ZTA) have high hardness, high strength, high toughness, and good thermal shock resistance (61). However, 3D rapid prototyping technologies including fused deposition modeling (FDM), selective laser sintering (SLS), stereolithography (SLA) can save time and allow the manufacture of any given shape and size model compared with the traditional part forming techniques. It has obvious advantages in the complex parts formation. At present, some important conclusions and achievements have been made in the preparation of ZTA components by SLA-3D printing technology (62-64).

Aluminum oxide is a highly biocompatible ceramic material that has good aesthetic properties but is associated with a high risk of fracture (65). Because of this key weakness, $\mathrm{ZrO}_{2}$ was introduced as a substitute for titanium. Zirconia is divided into monoclinic $(\mathrm{M})$, cubic $(\mathrm{C})$, and tetragonal $(\mathrm{T})$ phases according to different temperatures. The $\mathrm{M}$-phase is fragile at room temperature and therefore requires stabilization in technical applications to prevent the transition from the tetragonal ( $\mathrm{T}$ ) to the monoclinal $(\mathrm{M})$ phase. $\mathrm{Y}_{2} \mathrm{O}_{3}$ is a common stabilizer for maintaining the $\mathrm{ZrO}_{2}$ phase. $\mathrm{Y}_{2} \mathrm{O}_{3}$-stabilized quadrangular polycrystalline zirconia (Y-TZP) has high strength, toughness, and biocompatibility, which can cause a biological reaction similar to that of titanium. Therefore, Y-TZP is considered a 
potential substitute for titanium (66-68). However, $\mathrm{ZrO}_{2}$ exhibits structural instability when degraded at low temperatures due to the tetragonal $(\mathrm{T})$ to the monoclinal $(\mathrm{M})$ phase transition under wet or stress conditions. On this basis, some scholars developed $3 \mathrm{Y}$-TZP of co-doped $\mathrm{Nb}_{2} \mathrm{O}_{5}$ and $\mathrm{Ta}_{2} \mathrm{O}_{5}$ and $(\mathrm{Y}, \mathrm{Nb})$-TZP and (Y, Ta)-TZP. These (Y, Nb)-TZP and (Y, Ta)-TZP biomaterials have a good ability to support osteogenesis, and can be used as substitutes for existing titanium dental implant materials (69$71)$.

\section{INFLUENCE OF SURFACE MORPHOLOGY OF ZIRCONIA ON BONE INTEGRATION}

Surface modification strategies can be generalized into three broad categories: physical (sandblasting, plasma spraying, ion implantation, laser treatment, and pulsed magnetron sputtering), chemical (acid etching, anodizing, and micro-arc oxidation), and biological (protein absorption and ion interaction) (12).

Zhao et al. (72) found that the tensile strength increased from $116 \pm 13$ to $274 \pm 61 \mathrm{MPa}$ when 0.1 wt.\% of $\mathrm{Li}$ was added to Zn. Dai et al. (73) also found that the tensile strength and elongation were significantly improved compared with pure $\mathrm{Zn}$ when 0.5 wt.\% Li alloy was added. $\mathrm{A} \mathrm{ZrO}_{2}$ nano-film was constructed on the surface of $\mathrm{Zn}-0.1 \mathrm{Li}$ alloy (ZL) to control the corrosion rate of the matrix $(72,73)$.

Kawashima et al. investigated the surface characteristics of the annealed HAP/zirconia composite. They concluded that the HAP/zirconia has mechanical compatibility and a potential for good biocompatibility with bone tissue (74). $\mathrm{ZrO}_{2}$ has also shown a superior ability to induce bone formation in biological environments. In final, silver inhibits bacterial growth, thus reducing the likelihood of infection during surgery, but may also improve mineral deposition and the expression of osteogenic markers. Bone integration was studied by biochemical analysis as well as bone histomorphometry and computed tomography (75).

So far, sandblasting or acid erosion blasting (SLA), dipping and plasma spraying have been the main methods for surface modification of titanium implants with $\mathrm{ZrO}_{2}$ (76). Plasma spraying is a powerful surface modification tool with a wide selection of coating materials, such as metals, ceramics, and composites. Plasma spray coating can significantly improve the physical and chemical properties of the substrate material. By controlling the relevant parameters, the surface morphology, roughness, porosity, elemental composition, and crystallization degree can be easily controlled (77).

It has been reported that $\mathrm{ZrO}_{2}$ nanoparticle has better biocompatibility compared with other nanomaterials such as iron oxide, $\mathrm{TiO}_{2}$, and zinc oxide $(\mathrm{ZnO})$. Consistent with these results, other studies have reported that nanoparticles of $\mathrm{ZrO}_{2}$ can induce mild or no cytotoxic effects, and only few studies have shown mild cytotoxic potential $(78,79)$. Some researchers used $\mathrm{TiO}_{2}$ as a control group, which is a traditional nanomaterial with similar physical and chemical properties. $\mathrm{TiO}_{2}$ and $\mathrm{ZrO}_{2}$ nanoparticles were cultured with MC3T3-E1 to observe osteoblast activity, oxidative stress and cell morphology, and the reaction of osteogenesis. If $\mathrm{TiO}_{2}$ and $\mathrm{ZrO}_{2}$ nanoparticles are in high concentrations, the toxicity will produce a large number of ROS, and ROS in the cytotoxicity induced by $\mathrm{TiO}_{2}$ and $\mathrm{ZrO}_{2}$ nanoparticles plays a key role including the cell vitality, apoptosis and necrosis, and the changesin cell morphology of MC3T3- E1 cells $(80,81)$.

\section{APPLICATION OF $\mathrm{ZrO}_{2}$ IN IMPLANT ABUTMENT}

The white color of $\mathrm{ZrO}_{2}$ is also aesthetically beneficial, as it can overcome the problems of penetration and staining that cover the gums. Similarly, the non-metallic appearance of $\mathrm{ZrO}_{2}$ appeals to patients who require metal-free implants for aesthetic and other reasons. Among the metal-free implants, $\mathrm{ZrO}_{2}$ abutments are often chosen as the first choice, especially in the growing number of patients with thin gingival soft tissue.

\section{THE SHORTCOMINGS OF $\mathrm{ZrO}_{2}$ AS DENTAL BIOMATERIALS}

Due to its excellent mechanical properties, high-temperature stability, biological safety, and low thermal conductivity, zirconia ceramics have been widely used in clinical applications, especially in the restoration of posterior crowns and fixed bridges. However, under a relatively low temperature and humid environment, zirconia changes from a partially stable tetragonal phase to a monoclinic phase, that is, the phenomenon of low-temperature aging, which affects its mechanical properties $(82,83)$.

\section{CONCLUSION}

In this review, the application prospect and research status of $\mathrm{ZrO}_{2}$ in the dental clinic have prospected, and the $\mathrm{ZrO}_{2}$ based ceramics are reviewed. $\mathrm{ZrO}_{2}$ has wide application prospects in implant, post-core, tooth crown, and so on. Extensive in vitro and in vivo studies have demonstrated high fracture resistance and can be used in stress-bearing areas. The characteristics of the $\mathrm{ZrO}_{2}$ surface, such as the lack of plaque adhesion to the $\mathrm{ZrO}_{2}$ and the absence of micro gaps between the fixtures, also discourage bacterial invasion. $\mathrm{ZrO}_{2}$ platform restoration is a promising alternative to metal platform restoration. The biosafety of $\mathrm{ZrO}_{2}$ due to aging and wear of $\mathrm{ZrO}_{2}$ restorations should be further evaluated to guide the safe use of $\mathrm{ZrO}_{2}$ materials. The biocompatibility of $\mathrm{ZrO}_{2}$ has been well-proved. The experiments of Y-TZP in vivo and in vitro show that it has good biocompatibility and has no adverse reactions to cells and tissues. With the improvement of the technology in preparing $\mathrm{ZrO}_{2}$ and the modification of the surface of $\mathrm{ZrO}_{2}$, the biosafety of $\mathrm{ZrO}_{2}$ will be affected, which is beneficial to the application of $\mathrm{ZrO}_{2}$ as an implant in dentistry.

\section{AUTHOR CONTRIBUTIONS}

All authors listed have made a substantial, direct and intellectual contribution to the work, and approved it for publication. 


\section{REFERENCES}

1. Ingole $\mathrm{VH}$, Sathe $\mathrm{B}$, Ghule AV. Bioactive ceramic composite material stability, characterization. In: Fundamental Biomaterials: Ceramics. Duxford: Woodhead Publishing. (2018). p. 27396. doi: 10.1016/B978-0-08-102203-0.00012-3

2. Ram S, Singh G P. Advanced ZrO 2-Based ceramic nanocomposites for optical and other engineering applications. In: Composite Materials. Berlin: Springer (2017). p. 497-570. doi: 10.1007/978-3-662-49514-8_15

3. Ghasemi-Kahrizsangi S, Karamian E, Gheisari Dehsheikh H, GhasemiKahrizsangi A. A review on recent advances on magnesia-doloma refractories by nano-technology. J Water Environ Nanotechnol. (2017) 2:206-22. doi: 10.22090/jwent.2017.03.008

4. Sun T, Liu G, Ou L, Feng X, Chen A, Lai R, et al. Toxicity induced by zirconia oxide nanoparticles on various organs after intravenous administration in rats. J Biomed Nanotechnol. (2019) 15:728-41. doi: 10.1166/jbn.2019.2717

5. Wang J, Stevens, R. Surface toughening of TZP ceramics by low temperature ageing. Ceram Int. (1989) 15:15-21. doi: 10.1016/0272-8842(89)90004-7

6. Meyenberg $\mathrm{KH}$, Lüthy $\mathrm{H}$, Schärer P. Zirconia posts: a new allceramic concept for nonvital abutment teeth. J Esthet Dent. (1995) 7:73-80. doi: 10.1111/j.1708-8240.1995.tb00565.x

7. Camposilvan E, Leone R, Gremillard L, Sorrentino R, Zarone F, Ferrari M, et al. Aging resistance mechanical properties and translucency of different yttriastabilized zirconia ceramics for monolithic dental crown applications. Dent Mater. (2018) 34:879-90. doi: 10.1016/j.dental.2018.03.006

8. Priyadarshini B, Rama M, Chetan, Vijayalakshmi U. Bioactive coating as a surface modification technique for biocompatible metallic implants: a review. J Asian Ceram Soc. (2019) 7:397-406. doi: 10.1080/21870764.2019.1669861

9. Hanawa T. Zirconia versus titanium in dentistry: a review. Dental Mater J. (2020) 39:24-36. doi: 10.4012/dmj.2019-172

10. Grech J, Antunes E. Zirconia in dental prosthetics: a literature review. J Mater Res Technol. (2019) 8:4956-64. doi: 10.1016/j.jmrt.2019.06.043

11. Chen YW, Moussi J, Drury JL, Wataha JC. Zirconia in biomedical applications. Exp Rev Med Dev. (2016) 13:94563. doi: 10.1080/17434440.2016.1230017

12. Huang Q, Elkhooly TA, Liu X, Zhang R, Yang X, Shen Z, et al. Effects of hierarchical micro/ nano-topographies on the morphology, proliferation and differentiation of osteoblast-like cells. Colloids Surf B Biointerfaces. (2016) 145:37-45. doi: 10.1016/j.colsurfb.2016.04.031

13. Liu Y, Rath B, Tingart M, Eschweiler J. Role of implants surface modification in osseointegration: a systematic review. J Biomed Mater Res Part A. (2020) 108:470-84. doi: 10.1002/jbm.a.36829

14. Zafar MS, Fareed MA, Riaz S, Latif M, Habib SR, Khurshid Z. Customized therapeutic surface coatings for dental implants. Coatings. (2020) 10:568. doi: 10.3390/coatings10060568

15. Bosshardt DD, Chappuis V, Buser D. Osseointegration of titanium, titanium alloy and zirconia dental implants: current knowledge and open questions. Periodontology. (2017) 73:22-40. doi: 10.1111/prd.12179

16. Mishra S, Chowdhary R. PEEK materials as an alternative to titanium in dental implants: a systematic review. Clin Implant Dent Relat Res. (2019) 21:208-22. doi: 10.1111/cid.12706

17. Brunello G, Brun P, Gardin C, Ferroni L, Bressan E, Meneghello R, et al. Biocompatibility and antibacterial properties of zirconium nitride coating on titanium abutments: an in vitro study. PLoS ONE. (2018) 13:e0199591. doi: 10.1371/journal.pone.0199591

18. Pulgarin HLC, Albano MP. Sintering, microstrusture and hardness of different alumina-zirconia composites. Ceram Int. (2014) 40:5289-98. doi: 10.1016/j.ceramint.2013.10.102

19. Zhou M, Liu W, Wu H, Song X, Chen Y, Cheng L. Preparation of a defect-free alumina cutting tool via additive manufacturing based on stereolithographyOptimization of the drying and debinding processes. Ceram Int. (2016) 42:11598-602. doi: 10.1016/j.ceramint.2016.04.050

20. Kalyoncuoglu UT, Yilmaz B, Koc SG, Evis Z, Arpaci PU, Kansu G. Investigation of surface structure and biocompatibility of chitosan-coated zirconia and alumina dental abutments. Clin Implant Dent Relat Res. (2018) 20:1022-9. doi: 10.1111/cid.12665

21. Deng QX, Ou YS, Zhu Y, Zhao ZH, Liu B, Huang Q. Clinical outcomes of two types of cages used in transforaminal lumbar interbody fusion for the treatment of degenerative lumbar diseases: n-HA/PA66 cages versus PEEK cages. J Mater Sci Mater Med. (2016) 27:102. doi: 10.1007/s10856-016-5712-7

22. Yuan Y, Liu C, Huang M. The structure and performance of short glass fiber/high-density polyethylene/polypropylene composite pipes extruded using a shearing(-) drawing compound stress field. Materials. (2019) 12:1323. doi: $10.3390 / \mathrm{ma} 12081323$

23. Guertler A, Thomas P, Herzinger T. [Pseudo allergic reaction to metal implant]. Hautarzt. (2018) 69:14-5. doi: 10.1007/s00105-018-4184-8

24. Zhao W, He B, Zhou A, Li Y, Chen X, Yang Q. D-RADA16-RGDreinforced nano-hydroxyapatite/polyamide 66 ternary biomaterial for bone formation. Tissue Eng Regen Med. (2019) 16:177-89. doi: 10.1007/s13770-018-0171-5

25. Qu Y, Wang P, Man Y, Li Y, Zuo Y, Li J. Preliminary biocompatible evaluation of nano-hydroxyapatite/polyamide 66 composite porous membrane. Int J Nanomed. (2010) 5:429-35. doi: 10.2147/IJN.S10710

26. Sharifi F, Atyabi SM, Norouzian D, Zandi M, Irani S, Bakhshi H. Polycaprolactone/carboxymethyl chitosan nanofibrous scaffolds for bone tissue engineering application. Int J Biol Macromol. (2018) 115:2438. doi: 10.1016/j.ijbiomac.2018.04.045

27. Soult MD, Lien W, Savett DA, Gallardo FF, Vandewalle KS. Effect of high-speed sintering on the properties of a zirconia material. Gen Dent. (2019) 67:30-4.

28. de Oliveira GR, Pozzer L, Cavalieri-Pereira L, de Moraes PH, Olate S, de Albergaría Barbosa JR. Retraction: bacterial adhesion and colonization differences between zirconia and titanium implant abutments: an in vivo human study. J Periodontal Implant Sci. (2019) 49:58. doi: 10.5051/jpis.2019.49.1.58

29. Jungmann R, Szabo ME, Schitter G, Tang RYS, Vashishth D, Hansma $\mathrm{PK}$, et al. Local strain, and damage mapping in single trabeculae during three point bending tests. J Mech Behav Biomed Mater. (2011) 4:52334. doi: 10.1016/j.jmbbm.2010.12.009

30. Li J, Zuo Y, Cheng X, Yang W, Wang H, Li Y. Preparation and characterization of nano-hydroxyapatite/polyamide 66 composite GBR membrane with asymmetric porous structure. J Mater Sci Mater Med. (2009) 20:10318. doi: 10.1007/s10856-008-3664-2

31. Lu M, Liao J, Dong J, Wu J, Qiu H, Zhou X. An effective treatment of experimental osteomyelitis using the antimicrobial titanium/silver-containing nHP66 (nano-hydroxyapatite/polyamide-66) nanoscaffold biomaterials. Sci Rep. (2016) 6:39174. doi: 10.1038/srep39174

32. Ardila MAN, Costa HL, de Mello JDB. Influence of the ball material on friction and wear in microabrasion tests. Wear. (2020) 450:203266. doi: 10.1016/j.wear.2020.203266

33. Teles VC, de Mello JDB, da Silva WM Jr. Abrasive wear of multilayered/gradient CrAlSiN PVD coatings: Effect of interface roughness and of superficial flaws. Wear. (2017) 376:1691701. doi: 10.1016/j.wear.2017.01.116

34. Bajraktarova-Valjakova E, Korunoska-Stevkovska V, Kapusevska B, Gigovski N, Bajraktarova-Misevska C, Grozdanov A. Contemporary dental ceramic materials, a review: chemical composition, physical and mechanical properties, indications for use. Open Access Maced J Med Sci. (2018) 6:174255. doi: 10.3889/oamjms.2018.378

35. Piconi C, Condo SG, Kosmač T. Alumina-and zirconia-based ceramics for load-bearing applications. Adv Ceram Dent. (2014) 219-53. doi: 10.1016/B978-0-12-394619-5.00011-0

36. Aloise JP, Curcio R, Laporta MZ, Rossi L, da Silva AM, Rapoport A. Microbial leakage through the implant abutment interface of morse taper implant in vitro. Clin Oral Implants Res. (2010) 21:328-35. doi: 10.1111/j.1600-0501.2009.01837.x

37. do Nascimento C, Barbosa RE, Issa JP, Watanabe E, Ito IY, Albuquerque RF Jr. Bacterial leakage along the implant abutment interface of premachined or cast components. Int J Oral Maxillofac Surg. (2008) 37:177-80. doi: 10.1016/j.ijom.2007.07.026

38. Hermann JS, Schoolfield JD, Schenk RK, Buser D, Cochran DL. Influence of the size of microgap on crestal bone changes around titanium implants. A histometric evaluation of unloaded non-submerged implants in the canine mandible. J Periodontol. (2001) 72:1372-83. doi: 10.1902/jop.2001.72.10.1372

39. Harder S, Dimaczek B, Acil Y, Terheyden H, Freitag-Wolf S, Kern M. Molecular leakage at implant-abutment connection in vitro investigation of tightness of internal conical implant-abutment 
connections against endotoxin penetration. Clin Oral Investig. (2009) 14:427-32. doi: 10.1007/s00784-009-0317-x

40. Broggini N, McManus LM, Hermann JS, Medina R, Schenk RK, Buser D, et al. Peri-implant inflammation defined by the implant-abutment interface. J Dent Res. (2006) 85:473-8. doi: 10.1177/154405910608500515

41. Prakasam M, Locs J, Salma-Ancane K, Loca D, Largeteau A, Berzina-Cimdina L. Biodegradable materials and metallic implants-a review. J Funct Biomater. (2017) 8:44. doi: 10.3390/jfb8040044

42. Großner-Schreiber B, Teichmann J, Hannig M, Dorferv C, Wenderoth D, Ott S. Modified implant surfaces show different biofilm composition under in vivo conditions. Clin Oral Implants Res. (2009) 20:81726. doi: 10.1111/j.1600-0501.2009.01729.x

43. Rasouli R, Barhoum A, Uludag H. A review of nanostructured surfaces and materials for dental implants: surface coating, patterning and functionalization for improved performance. Biomater Sci. (2018) 6:1312-38. doi: 10.1039/C8BM00021B

44. Zhang K, Van Le Q. Bioactive glass coated zirconia for dental implants: a review. J Compos Compounds. (2020) 2:10-7. doi: 10.29252/jcc.2.1.2

45. Chang HI, Wang Y. Cell responses to surface and architecture of tissue engineering scaffolds. In: Regenerative Medicine and Tissue Engineering-Cells and Biomaterials. InTechOpen (2011). doi: 10.5772/21983

46. Wakabayashi H, Yamauchi K, Kobayashi T, Yaeshima T, Iwatsuki K, Yoshie H. Inhibitory effects of lactoferrin on growth and biofilm formation of Porphyromonas gingivalis and Prevotella intermedia. Antimicrobial Agents Chemother. (2009) 53:3308-16. doi: 10.1128/AAC.01688-08

47. Lima EMCX, Koo H, Vacca-Smith AM, Rosalen PL, Del Bel Cury AA. Adsorption of salivary and serumproteins, and bacterial adherence on titanium and zirconia ceramic surfaces. Clin Oral Implants Res. (2008) 19:7805. doi: 10.1111/j.1600-0501.2008.01524.x

48. Sardin S, Morrier J, Benay G, Barsotti O. In vitro streptococcal adherence on prosthetic and implant materials. Interactions with physicochemical surface properties. J Oral Rehabil. (2004) 31:140-8. doi: 10.1046/j.0305-182X.2003.01136.x

49. Nikam A, Pagar T, Ghotekar S, Pagar K, Pansambal S. A review on plant extract mediated green synthesis of zirconia nanoparticles and their miscellaneous applications. J Chem Rev. (2019) 1:154-63. doi: 10.33945/SAMI/JCR.2019.3.1

50. Ostroushko AA, Grzhegorzhevskii KV, Medvedeva SYE, Gette IF, Tonkushina MO, Gagarin IYD, et al. Physicochemical and biochemical properties of the Keplerate-type nanocluster polyoxomolybdates as promising components for biomedical use. Nanosyst Phys Chem Mathe. (2021) 12:81-112. doi: 10.17586/2220-8054-2021-12-1-81-112

51. Fakhardo AF, Anastasova EI, Gabdullina SR, Solovyeva AS, Saparova VB, Chrishtop VV. Toxicity patterns of clinically relevant metal oxide nanoparticles. ACS Appl Bio Mater. (2019) 2:4427-35. doi: 10.1021/acsabm.9b00615

52. Degidi M, Artese L, Scarano A, Perrotti V, Gehrke P, Piattelli A. Inflammatory infiltrate microvessel density, nitric oxide synthase expression, vascular endothelial growth factor expression, and proliferative activity in peri-implant soft tissues around titanium and zirconium oxide healing caps. J Periodontol. (2006) 77:73-80. doi: 10.1902/jop.2006.77.1.73

53. El-Bassyouni GT, Eshak MG, Barakat IAH, Khalil WKB. Immunotoxicity evaluation of novel bioactive composites in male mice as promising orthopaedic implants. Cent Euro J Immunol. (2017) 42:54. doi: 10.5114/ceji.2017.67318

54. Dobrzański LA, Dobrzańska-Danikiewicz AD, Achtelik-Franczak A, Dobrzański LB, Hajduczek E, Matula G. Fabrication technologies of the sintered materials including materials for medical and dental application. In: Powder Metallurgy-Fundamentals and Case Studies. Rijeka: InTech (2017). p. 17-52. doi: 10.5772/6 5376

55. Sennerby L, Dasmah A, Larsson B, Iverhed M. Bone tissue responses to surface-modified zirconia implants: a histomorphometric and removal torque study in the rabbit. Clin Implant Dent Relat Res. (2005) 7:S1320. doi: 10.1111/j.1708-8208.2005.tb00070.x

56. Viswanathan V, Laha T, Balani K, Agarwal A, Seal S. Challenges and advances in nanocomposite processing techniques. Mater Sci Eng R Rep. (2006) 54:12185. doi: 10.1016/j.mser.2006.11.002
57. Glauser R, Sailer I, Wohlwend A, Studer S, Schibli M, Schärer P. Experimental zirconia abutments for implant-supported single-tooth restorations in aesthetically demanding regions: 4 -year results of a prospective clinical study. Int J Prosthodont. (2004) 17:285-90.

58. Tschernitschek H, Borchers L, Geurtsen W. Nonalloyed titanium as a bioinert metal: a review. Quintessence Int. (2005) 36:523-30.

59. Macan J, Sikirić MD, Deluca M, Bermejo R, Baudin C, Plodinec M. Mechanical properties of zirconia ceramics biomimetically coated with calcium deficient hydroxyapatite. J Mech Behav Biomed Mater. (2020) 111:104006. doi: 10.1016/j.jmbbm.2020.104006

60. Quan $\mathrm{R}$, Yang $\mathrm{D}$, Wu X, Wang $\mathrm{H}$, Miao X, Li W. In vitro and in vivo biocompatibility of graded hydroxyapatite-zirconia composite bioceramic. $J$ Mater Sci Mater Med. (2008) 19:183-7. doi: 10.1007/s10856-006-0025-x

61. Wu $\mathrm{H}$, Liu $\mathrm{W}, \mathrm{He} \mathrm{R}$, Wu Z, Jiang Q, Song X. Fabrication of dense zirconia-toughened alumina ceramics through a stereolithographybased additive manufacturing. Ceramics International. (2017) 43:96872. doi: 10.1016/j.ceramint.2016.10.027

62. Felgueiras HP, Migonney V. Cell spreading morphology variations as a result of protein adsorption bioactive coating on Ti6Al4V surfaces. IRBM. (2016) 37:165-71. doi: 10.1016/j.irbm.2016.03.006

63. Fraioli R, Dashnyam K, Kim JH, Perez RA, Kim HW, Gil J. Surface guidance of stem cell behavior: chemically tailored co-presentation of integrin-binding peptides stimulates osteogenic differentiation in vitro and bone formation in vivo. Acta Biomater. (2016) 43:269-81. doi: 10.1016/j.actbio.2016.07.049

64. Huang Q, Liu X, Elkhooly TA, Zhang R, Shen Z, Feng Q. A novel titania/calcium silicate hydrate hierarchical coating on titanium. Colloids Surf B Biointerfaces. (2015) 134:169-77. doi: 10.1016/j.colsurfb.2015.07.002

65. Ho GW, Matinlinna JP. Insights on ceramics as dental materials. Part I: ceramic material types in dentistry. Silicon. (2011) 3:109-15. doi: 10.1007/s12633-011-9078-7

66. Costa AMM. Development of Bioactive Materials for Dental Implants Using Powder Metallurgy. Portugal: Master thesis (2016).

67. Zhuang LF, Jiang HH, Qiao SC, Appert C, Si MS, Gu YX, et al. The roles of extracellular signalregulated kinase $1 / 2$ pathway in regulating osteogenic differentiation of murine preosteoblasts MC3T3-E1 cells on roughened titanium surfaces. J Biomed Mater Res A. (2012) 100:12533. doi: 10.1002/jbm.a.33247

68. Galli C, Passeri G, Ravanetti F, Elezi E, Pedrazzoni M, Macaluso GM. Rough surface topography enhances the activation of Wnt/beta-catenin signaling in mesenchymal cells. J Biomed Mater Res A. (2010) 95:68290. doi: 10.1002/jbm.a.32887

69. Feng B, Weng J, Yang BC, Qu SX, Zhang XD. Characterization of surface oxide films on titanium and adhesion of osteoblast. Biomaterials. (2003) 24:4663-70. doi: 10.1016/S0142-9612(03)00366-1

70. Chani MTS, Khan SB, Asiri AM, Karimov KS, Rub MA. Photo-thermoelectric cells based on pristine $\alpha-\mathrm{Al}_{2} \mathrm{O}_{3}$ co-doped $\mathrm{CdO}$, CNTs and their single and bi-layer composites with silicone adhesive. J Taiwan Inst Chem Eng. (2015) 52:93-9. doi: 10.1016/j.jtice.2015.02.005

71. Gittens RA, McLachlan T, Olivares-Navarrete R, Cai Y, Berner S, Tannenbaum $\mathrm{R}$. The effects of combined micron-/submicron-scale surface roughness and nanoscale features on cell proliferation and differentiation. Biomaterials. (2011) 32:3395-403. doi: 10.1016/j.biomaterials.2011.01.029

72. Zhao Sh, Seitz J-M. Eifler R, Maier HJ, Guillory II RJ, Earley EJ, et al. ZnLi alloy after extrusion and drawing: Structural, mechanical characterization, and biodegradation in abdominal aorta of rat. Mater Sci Eng C Mater Biol Appl. (2017) 76::301-12. doi: 10.1016/j.msec.2017.02.167

73. Satish P, Satuluri S, Sivarao S. Recent Advances in Material Sciences. In Satish P, editor. Select Proceedings of ICLIET. Berlin: Springer (2108). p. 771-72.

74. Kawashima N, Soetanto K, Watanabe K, Ono K, Matsuno T. The surface characteristics of the sintered body of hydroxyapatitezirconia composite particles. Colloids Surf B Bioint. (1997) 10:2327. doi: 10.1016/S0927-7765(97)00041-6

75. Salem NA, Abo TA, Aboushelib MN. Biomechanical and histomorphometric evaluation of osseointegration of fusion-sputtered zirconia implants. J Prosthodont. (2013) 22:261-7. doi: 10.1111/j.1532-849X.2012. 00940.x

76. Aboushelib MN, Salem NA, Taleb AL, El MN. Influence of surface nanoroughness on osseointegration of zirconia implants in rabbit femur heads 
using selective infiltration etching technique. J Oral Implantol. (2013) 39:58390. doi: 10.1563/AAID-JOI-D-11-00075

77. Wennerberg A, Albrektsson T. Effects of titanium surface topography on bone integration: a systematic review. Clin Oral Implants Res. (2009) 20(Suppl. 4):172-84. doi: 10.1111/j.1600-0501.2009.01775.x

78. Conserva E, Lanuti A, Menini M. Cell behavior related to implant surfaces with different microstructure and chemical composition: an in vitro analysis. Int J Oral Maxillofac Implants. (2010) 25:1099-107.

79. Conserva E, Menini M, Ravera G, Pera P. The role of surface implant treatments on the biological behavior of SaOS-2 osteoblast-like cells. An in vitro comparative study. Clin Oral Implants Res. (2013) 24:8809. doi: 10.1111/j.1600-0501.2011.02397.x

80. Le Guehennec L, Soueidan A, Layrolle P, Amouriq Y. Surface treatments of titanium dental implants for rapid osseointegration. Dent Mater. (2007) 23:844-54. doi: 10.1016/j.dental.2006.06.025

81. Baldi D, Menini M, Pera F, Ravera G, Pera P. Plaque accumulation on exposed titanium surfaces and peri-implant tissue behavior. A preliminary 1-year clinical study. Int J Prosthodont. (2009) 22:447-55.

82. Sanon C, Chevalier J, Douillard T, Kohal RJ, Coelho PG, Hjerppe $\mathrm{J}$, et al. Low temperature degradation and reliability of one-piece ceramic oral implants with a porous surface. Dent Mater. (2013) 29:38997. doi: 10.1016/j.dental.2013.01.007
83. Frigan K, Chevalier J, Zhang F, Spies BC. Is a zirconia dental implant safe when it is available on the market? Ceramics. (2019) 2:568-77. doi: 10.3390/ceramics20 40044

Conflict of Interest: The authors declare that the research was conducted in the absence of any commercial or financial relationships that could be construed as a potential conflict of interest.

Publisher's Note: All claims expressed in this article are solely those of the authors and do not necessarily represent those of their affiliated organizations, or those of the publisher, the editors and the reviewers. Any product that may be evaluated in this article, or claim that may be made by its manufacturer, is not guaranteed or endorsed by the publisher.

Copyright (c) 2021 Lin, Yin and Mo. This is an open-access article distributed under the terms of the Creative Commons Attribution License (CC BY). The use, distribution or reproduction in other forums is permitted, provided the original author(s) and the copyright owner(s) are credited and that the original publication in this journal is cited, in accordance with accepted academic practice. No use, distribution or reproduction is permitted which does not comply with these terms. 